\title{
Determination of xylem water flow velocity of some Prunus shoots by dye infusion technique
}

\author{
Boya infüzyon tekniği ile bazı Prunus sürgünlerinin ksilem su akış hızının belirlenmesi
}

\author{
Servet ARAS ${ }^{1 *}$ iD, \\ ${ }^{1}$ Yozgat Bozok University, Faculty of Agriculture, Department of Horticulture, Yozgat, Turkey
}

1https://orcid.org/0000-0002-0347-6552

To cite this article:

Aras, S. (2021). Determination of xylem water flow velocity of some Prunus shoots by dye infusion technique. Harran Tarım ve Gıda Bilimleri Dergisi, 25(3): 287-292. DOI: $10.29050 /$ harranziraat.918418

*Address for Correspondence: Servet ARAS

e-mail:

servet.aras@yobu.edu.tr

\section{Received Date:}

16.04.2021

Accepted Date:

12.07.2021
(C) Copyright 2018 by Harran University Faculty of Agriculture. Available on-line at www.dergipark.gov.tr/harranziraat
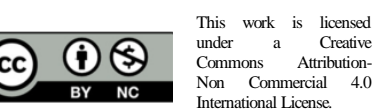

\section{ABSTRACT}

Water movement in xylem vessel presents hydraulic system. The hydraulic system may encounter embolism (cavitation) caused by environmental stresses. Tracer dyes are distributed within the xylem and can be monitored by sectioning the tissue called dye infusion technique. The current experiment determined the optimal conditions for acid fuchsin dye infusion technique to monitor the water-conducting pathways in shoots of sweet cherry and peach trees. Shoots from 18-year-old sweet cherry cultivar 0900 Ziraat grafted onto Gisela 5 and 2-year-old peach cultivar Rich May grafted onto Garnem and GF 677 were used in the experiment. Xylem functionality and xylem water flow velocity $\left(V_{x w}\right)$ were evaluated by dye infusion technique. The intensity of acid fuchsin staining in the shoots increased with dye concentration. In sweet cherry trees, $V_{x w}$ decreased with the time course and $120 \mathrm{mn}$ had the lowest $V_{x w}$ value. In peach, $V_{x w}$ of GF 677 was found further compared to Garnem. The experiment showed that the dye infusion technique is reliable for the visualization of waterconduction pathways and xylem functionality. Furthermore, the technique can be used in the studies of bud dormancy break of trees and stresses.

Key Words: Acid fuchsin, Peach, Sweet cherry, Xylem, Water flow

öz

Ksilem demetindeki su hareketi hidrolik sistemi temsil etmektedir. Hidrolik sistem, çevresel streslerin neden olduğu emboli (kavitasyon) ile karşılaşabilmektedir. İzleyici boyalar ksilem içinde dağılabilmekte ve boya infüzyon adı verilen teknik ile dokuyu bölümlere ayırarak izlenebilmektedir. Mevcut çalışma, kiraz ve şeftali ağaçlarının sürgünlerinde su iletim yollarını izlemek için asit fuksin boya infüzyon tekniği için en uygun koşulları belirlemiştir. Gisela 5 üzerine aşılı 18 yaşındaki 0900 Ziraat kiraz çeşidi ve Garnem ve GF 677 üzerine aşıı 2 yaşındaki Rich May şeftali çeşidinin sürgünleri çalışmada kullanılmıştır. Ksilem işlevi ve ksilem su akış hızı $\left(V_{x w}\right)$ boya infüzyon tekniği ile değerlendirilmiştir. Sürgünlerde asit fuksin boyamasının yoğunluğu, boya konsantrasyonu ile artmıştır. Kiraz ağaçlarında, $V_{x w}$ zamanla azalmış ve 120 dakika en düşük Vxw değere olmuştur. Şeftalide, GF 677'nin Vxw'si Garnem'e kıyasla daha fazla bulunmuştur. Çalışma, boya infüzyon tekniğinin su iletim yollarının ve ksilem işlevinin görselleştirilmesi için güvenilir olduğunu göstermiştir. Ayrıca bu teknik, ağaçların tomurcuk dormansilerinin kırılmalarında ve stres çalışmalarında kullanılabilir.

Anahtar Kelimeler: Asit fuksin, Şeftali, Kiraz, Ksilem, Su akışı

\section{Introduction}

Water is necessary for the life of plants taking many pivotal roles in photosynthesis, plant metabolisms, cell enlargement, etc. (Boyer 1988; Tezara et al., 1999; Çıkman et al., 2011). Water is mainly transported through xylem vessel in whole plant. Xylem vessels consist of dead cells that 
transport water and inorganic solutes. Water flowing through xylem conduits presents hydraulic system (Liu et al., 2015). The hydraulic system may encounter limitation to the functionality of water transport in xylem called embolism (cavitation) caused by environmental stresses including drought (Hargrave et al., 1994) and salinity (Rajput et al., 2015). Reduction in xylem functionality also leads decrease in water uptake. Decline in xylem functionality during fruit development have been found in many fruits such as apple (Miqueloto et al., 2014), sweet cherry (Grimm et al., 2017). Loss in xylem functionality causes calcium ( $\mathrm{Ca}$ ) deficiency, because $\mathrm{Ca}$ is translocated through the xylem (Martinez et al., 2020; Aras et al., 2021).

Different methods have been used to study xylem functionality. Magnetic resonance imaging (MRI) (Grimm et al., 2017) and centrifuge technique (Cochard et al., 2005) are utilized to visualize xylem functionality and embolism. Furthermore, tracer dyes are distributed within the xylem and can be monitored by sectioning the tissue called dye infusion technique. Such methodology could provide for a less expensive approach. Acid fuchsin, xylem-mobile dye, is utilized in the dye infusion technique to observe water movement in the xylem (Dražeta et al., 2004; Chatelet et al., 2008). Miqueloto et al. (2014) used acid fuchsin to monitor xylem functionality and they reported that earlier loss of xylem functionality of apple fruits caused bitter pit due to the lack of $\mathrm{Ca}$ translocation. Acid fuchsin infusion technique was also used in shoots of Pieris japonica D. Don trees to visualize water-conducting pathways (Umebayashi et al., 2007).

Xylem functionality has been studied by several methods (Cochard et al., 2005, 2010), but the methods need high cost appliances. The current experiment represents low cost method and determined the optimal conditions for acid fuchsin dye infusion technique to monitor the water-conducting pathways in shoots of sweet cherry and peach trees. The concentration of the dye required to visualize water-conducting pathways and the duration of dye exposure time were determined in sweet cherry and peach trees. Moreover, the study characterized water movement velocity as xylem water flow velocity and compared between two common peach rootstocks, Garnem and GF 677.

\section{Material and Methods}

Shoots from 18-year-old sweet cherry cultivar 0900 Ziraat (Prunus avium L.) grafted onto Gisela 5 (Prunus cerasus $\times$ Prunus canescens) and 2-yearold peach cultivar Rich May (Prunus persica Batsch) grafted onto Garnem (Prunus dulcis $\times$ P. persica) and GF 677 (Prunus dulcis x P. persica) were used in the experiment. Twelve trees and 2 shoots per tree were used. Xylem functionality and xylem water flow velocity were evaluated by dye infusion technique. The study included two experiments.

Experiment I was conducted on the shoots of the sweet cherry trees grown in orchard. The study site is located in the central region of Yozgat Province in Turkey, which has a mean annual precipitation of $570 \mathrm{~mm}$ and a mean temperature of $9.2^{\circ} \mathrm{C}$. Experiment II was performed in shoots of peach trees grown in pots in a greenhouse. The peach saplings were planted in $10 \mathrm{~L}$ pots filled with peat and perlite $(4: 1)$ in the previous year.

\section{Xylem functionality and xylem water flow velocity}

Xylem functionality and xylem water flow velocity were determined by dye infusion technique. The shoots were harvested by $20 \mathrm{~cm}$ length in beginning of April. Collected shoots were 1 year old and represented shoots and xylem that had formed during the past year's growing season. To prevent embolism, shoots were immediately placed in aqueous acid fuchsin at $25^{\circ} \mathrm{C}$. In Experiment I, sweet cherry shoots were incubated in 0.1 or $0.5 \%(\mathrm{w} / \mathrm{v})$ aqueous acid fuchsin during different periods $(30,60,90$ and 120 minutes). In Experiment II, peach shoots were incubated in 0.5 and $1.0 \%(\mathrm{w} / \mathrm{v})$ aqueous acid fuchsin during different periods $(30$ and 60 minutes). $0.1 \%$ aqueous acid fuchsin and 90 and 120 minutes periods were not chosen in the Experiment II, because $0.1 \%$ aqueous acid fuchsin was not enough to observe dye movement and 30 and 60 minutes were found better to monitor the dye moves according to Experiment $I$. The doses of $0.1,0.5$ and $1 \%(\mathrm{w} / \mathrm{v})$ aqueous acid fuchsin were used in many experiments to study xylem functionality (Umebayashi et al., 2007; Inch and Ploetz, 2012). The shoot tips were not cut due to preventing water loss through evaporation. End of the each incubation period, each shoot was cut starting with shoot tip until observing staining intensity. The length of the stained part of the shoots along the path of dye movement was 
measured by a digital compass.

Xylem water flow velocity $\left(\mathrm{V}_{\mathrm{xw}}\right)$ represented xylem functionality and was calculated using the equation given below and expressed as $\mathrm{mm} \mathrm{h}^{-1}$ :

$\mathrm{V}_{\mathrm{XW}}=$ length of the stained part of the shoot $(\mathrm{mm})$ / dye infusion period (h).

Colorimeter (Minolta model CR 400) was used to determine shoot cortex coloration (the staining intensity of the xylem). Lightness (L) and hue angle $\left(h^{\circ}\right)$ of the shoots transverse section were measured and high values of $L \times h^{\circ}$ indicate higher lightness (stronger white staining and lighter red staining), which demonstrates lower functionality of the xylem (Miqueloto et al., 2014).

The statistical analyses were performed with the statistical software package SPSS, version 20.0. Data were subjected to two-way ANOVA and separated by the Duncan's test at a significance level of $P<0.05$.

\section{Results and Discussion}

In Experiment I, the intensity of acid fuchsin staining increased with dye concentration. When the shoots were incubated in $0.1 \%$ acid fuchsin, it was difficult to distinguish the dye color from the background xylem color. Thus, the related parameters were measured using $0.5 \%$ acid fuchsin. The dye distributed in the inner part of the shoots (Figure 1). Figure 1 shows a shoot ring at the maximum height that the xylem was stained with acid fuchsin. The bark tissue was also stained with the dye shown in Figure 2.

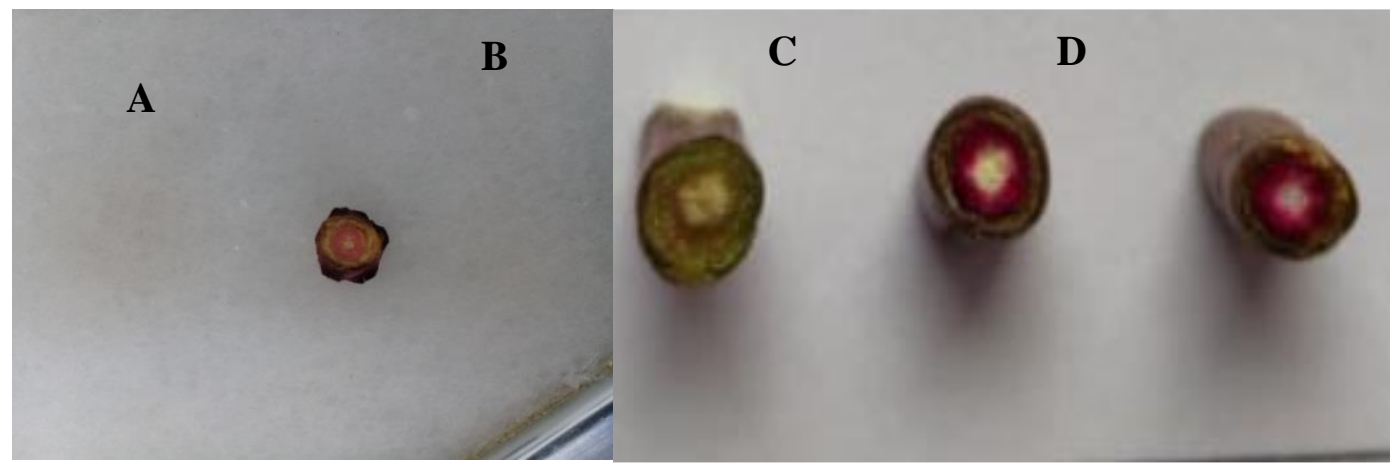

Figure 1. The maximum height that the xylem was stained with acid fuchsin, A- sweet cherry $+0.5 \%$ acid fuchsin, B- control of peach ( $0 \%$ acid fuchsin), C- peach $+0.5 \%$ acid fuchsin, D- peach $+1.0 \%$ acid fuchsin

Şekil1. Asit fuksin ile boyanan ksilemin en üst kısmı, A-kiraz+0.5\% asit fuksin, B- şeftalinin kontrolü ( $0 \%$ asit fuksin), $C$ - şeftali+0.5\% asit fuksin, $D$ - şeftali $+1.0 \%$ asit fuksin

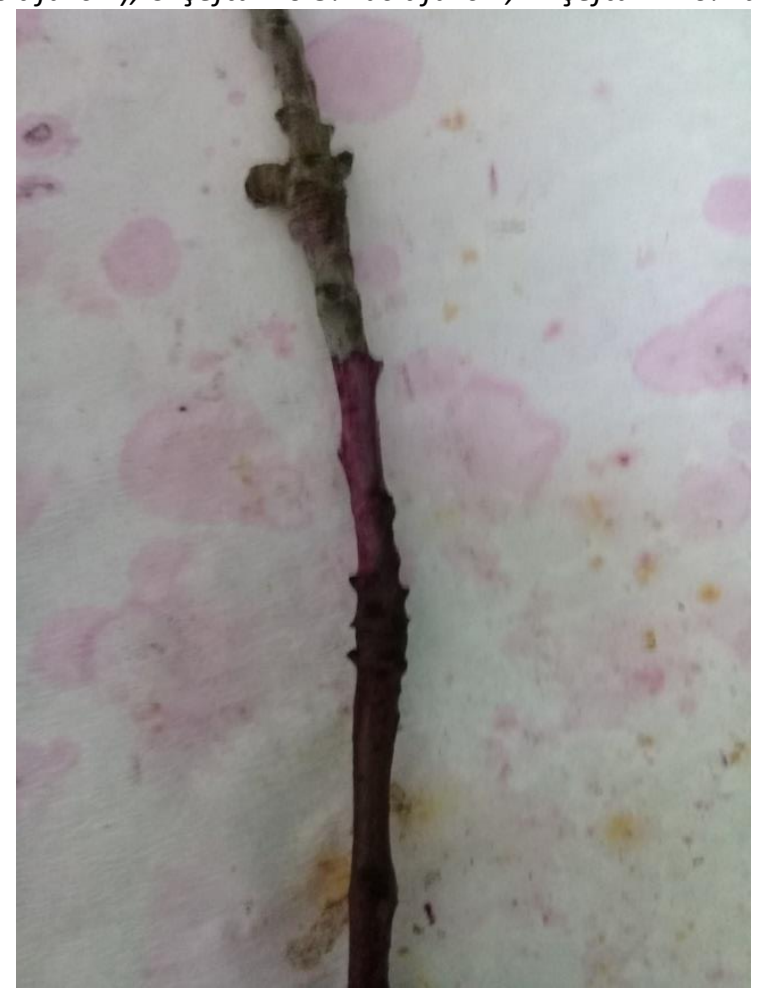

Figure 2. Staining of the bark of sweet cherry shoot

Şekil 2. Kiraz sürgününün kabuğunun boyanması 
Water is transported in the xylem and function of xylem is of importance to plants due to affecting hydraulic conductivity (Meinzer et al., 2001). Xylem functionality can be impaired by embolism resulting in an embolized xylem conduit that is unable to transport water (Améglio et al., 2002). Xylem functionality and xylem have been examined by several methods including magnetic resonance imaging (MRI), centrifuge technique and Cavitron spinning technique (Cochard et al., 2005, 2010; Grimm et al., 2017). In the current experiment, feeding acid fuchsin to the shoots of the sweet cherry and peach trees resulted in the uptake into xylem. Acid fuchsin distribution was monitored by sectioning of shoots followed by measuring shoot cortex coloration. The concentration of acid fuchsin did not decrease gradually in the shoots because acid fuchsin is negatively charged dye rarely adheres to cell wall components (Sano et al., 2005).

$V_{x w}$ decreased with the time course and 120 $\mathrm{mn}$ had the lowest $\mathrm{V}_{\mathrm{xw}}$ value in sweet cherry shoots (Table 1). An increase in the shoot cortex coloration ( $L \times h^{\circ}$ value) demonstrated a loss of $x y l e m$ function. The lowest $L x h^{\circ}$ value was found in shoots exposed to dye infusion for $90 \mathrm{mn}$.
Table 1. Xylem water flow velocity $(\mathrm{V} x \mathrm{w})$ and shootcortex coloration ( $\mathrm{L} \times \mathrm{h}^{\circ}$ value) in sweet cherry shoot

Çizelge 1. Kiraz sürgünlerinde ksilem su akış hızı $(V x w)$ ve sürgün korteks renklenmesi ( $L x h^{\circ}$ değeri)

\begin{tabular}{cccc}
\hline $\begin{array}{c}\text { Concentration } \\
\text { of acid } \\
\text { fuchsin }\end{array}$ & $\begin{array}{c}\text { Duration } \\
(\mathrm{mn})\end{array}$ & $\mathrm{V}_{\mathrm{xw}}\left(\mathrm{mm} \mathrm{h}^{-1}\right)$ & $\mathrm{Lx} \mathrm{h}^{\circ}$ value \\
\hline $30 \mathrm{mn}$ & $69.0 \mathrm{a}$ & $1304 \mathrm{a}$ \\
$0.5 \%$ & $60 \mathrm{mn}$ & $54.3 \mathrm{ab}$ & $855 \mathrm{ab}$ \\
& $90 \mathrm{mn}$ & $42.2 \mathrm{~b}$ & $277 \mathrm{~b}$ \\
& $120 \mathrm{mn}$ & $41.0 \mathrm{~b}$ & $651 \mathrm{ab}$
\end{tabular}

Means separation within column by Duncan's multiple range test. $\mathrm{P}<0.05$

In Experiment II, 0.1\% acid fuchsin was not chosen and 0.5 and $1.0 \%$ acid fuchsin were used in peach shoots. The dye ascended shoots more rapidly compared to shoots of the sweet cherry. Thus, xylem functionality was observed in 30 and $60 \mathrm{mn}$. In Experiment II, two peach rootstocks were compared. Vxw of GF 677 was found further compared to Garnem (Table 2). Moreover, $V_{x w}$ of both rootstocks was higher in $30 \mathrm{mn}$. The lowest $\mathrm{L}$ $x h^{\circ}$ value was found in shoots of both rootstocks exposed to $1.0 \%$ dye infusion for $30 \mathrm{mn}$.

Table 2. Xylem water flow velocity $(\mathrm{V} x w)$ and shoot cortex coloration ( $\mathrm{L} x \mathrm{~h} \circ$ value) in peach shoot Çizelge 2. Şeftali sürgünlerinde ksilem su akış hızı $\left(V_{x w}\right)$ ve sürgün korteks renklenmesi ( $L x h^{\circ}$ değeri)

\begin{tabular}{|c|c|c|c|c|}
\hline Variety/Rootstock & $\begin{array}{l}\text { Concentration of acid } \\
\text { fuchsin }\end{array}$ & Duration (mn) & $V_{x w}\left(m h^{-1}\right)$ & $L x h^{\circ}$ value \\
\hline \multirow{7}{*}{ Rich May/Garnem } & & $30 \mathrm{mn}$ & $154.0 \mathrm{a}$ & $2611.9 \mathrm{~b}$ \\
\hline & $0.5 \%$ & & & \\
\hline & & $60 \mathrm{mn}$ & $138.6 \mathrm{~b}$ & 2690.9 a \\
\hline & & & & \\
\hline & & $30 \mathrm{mn}$ & $190.0 \mathrm{a}$ & $2102.8 \mathrm{~b}$ \\
\hline & $1.0 \%$ & & & \\
\hline & & $60 \mathrm{mn}$ & $156.0 \mathrm{~b}$ & $2932.1 \mathrm{a}$ \\
\hline \multirow{7}{*}{ Rich May/GF 677} & & $30 \mathrm{mn}$ & 240.7 a & $2200.8 b$ \\
\hline & $0.5 \%$ & & & \\
\hline & & $60 \mathrm{mn}$ & $169.0 \mathrm{~b}$ & $2313.8 \mathrm{a}$ \\
\hline & & & & \\
\hline & & $30 \mathrm{mn}$ & $302.7 \mathrm{a}$ & $2056.4 \mathrm{~b}$ \\
\hline & $1.0 \%$ & & & \\
\hline & & $60 \mathrm{mn}$ & $170.7 \mathrm{~b}$ & $2286.2 \mathrm{a}$ \\
\hline
\end{tabular}

Means separation within column by Duncan's multiple range test. $\mathrm{P}<0.05$

The xylem functionality was studied by dye infusion technique in many fruits. Grimm et al. (2017) studied acid fuchsin feeding to the pedicel of detached sweet cherry fruits resulted in distribution of the dye via xylem. Miqueloto et al. (2014) found that xylem functionality decreased by apple fruit development. Furthermore, they stated that increment in $L x h^{\circ}$ value was observed throughout fruit development that shows decrease in cortex coloration. In the present study, the lowest shoot cortex coloration was observed shoots of the sweet cherry exposed to dye infusion for $90 \mathrm{mn}$. In addition to shoot cortex coloration, we evaluated $V_{x w}$ in the shoots. $V_{x w}$ 
decreased with the time course and there was no statistical difference between 90 and $120 \mathrm{mn}$. In shoots of peach trees, the higher $\mathrm{V}_{\mathrm{xW}}$ and the lowest $L \times h^{\circ}$ value were found in shoots of both rootstocks exposed to $1.0 \%$ dye infusion for 30 $\mathrm{mn}$. In a previous experiment, Umebayashi et al. (2007) reported that acid fuchsin is relatively fast and most xylem cells are stained within $2 \mathrm{~h}$, thus dye injection period should be less than $2 \mathrm{~h}$. The results of the current experiment are convenient with the study.

Water movement and the distribution via xylem possess importance, because the value of $V_{x w}$ may show the strength of a shoot xylem against environmental challenges. Drought and salinity stress caused xylem vulnerability to cavitation (Cochard et al., 2008; Stiller, 2009). $V_{x w}$ determined by dye infusion technique represents xylem functionality of shoots to cavitation and challenges. Xylem inflow delivers essential minerals such as calcium to the fruit, leaf and other tissues (Aras et al., 2021; Li et al., 2021) and the dye infusion technique may be used to determine early diagnosis of calcium deficiency. Furthermore, this technique could be used to determine bud dormancy release studies. Xylem functionality decreases during bud dormancy and this method may be an indicator of bud dormancy release period. In the present study, $V_{x w}$ value changed depending on the tree age and rootstocks. Water movement in xylem was found lower in old sweet cherry trees compared to young peach trees. Furthermore, the differences between Garnem and GF 677 were observed. Rootstock influences the scion and increases the plant tolerance against environmental stresses (Bolat et al., 2016; Aras and Eşitken, 2019; Aras et al., 2019; Polat, 2021). In the present study, two peach rootstocks were compared and $V_{x w}$ of GF 677 was found further compared to Garnem. GF 677 is more dwarfing rootstock than Garnem (Aras and Keles, 2021). $V_{x w}$ may be related to the anatomy of plants. In a previous experiment, xylem size and number were found further in GF 677 compared to Garnem (Aras et al., 2021).

\section{Conclusion}

The experiment showed that the dye infusion technique represents a low cost method for the visualization of water-conduction pathways and xylem functionality. Furthermore, the technique can be used to determine bud break of trees and stress studies. $V_{w x}$ should be a good parameter for comparison of plants under stress conditions. The study offers that $0.5 \%$ acid fuchsin dye infusion for $90 \mathrm{mn}$ is appropriate for old trees and $1.0 \%$ acid fuchsin dye infusion for $30 \mathrm{mn}$ is appropriate for young trees in Prunus to visualize xylem functionality. The study concludes that dye infusion technique should be optimized for the species and tissues.

Conflict of Interest: The author declares no conflict of interest.

Author Contribution: SA conducted and analyzed the study and wrote the manuscript.

\section{References}

Améglio, T., Bodet, C., Lacointe, A., \& Cochard, H. (2002). Winter embolism, mechanisms of xylem hydraulic conductivity recovery and springtime growth patterns in walnut and peach trees. Tree Physiology, 22(17), 1211-1220.

Aras, S., \& Eşitken, A. (2019). Responses of Cherry Plant Grafted onto CAB-6P, MaxMa 14 and Mazzard Rootstocks to Short Term Salinity. Journal of Agricultural Studies, 7(3), 29-37.

Aras, S., \& Keles, H. (2021) Comparison of relative growth rates of peach plants grafted onto Garnem and GF677. III. Uluslararası New York Kültürel Etkileşim ve Akademik Çalışmalar Kongresi, 29-30 Mayıs, New York.

Aras, S., Eşitken, A., \& Karakurt, Y. (2019). Morphological and physiological responses and some wrky genes expression in cherry rootstocks under salt stress. Spanish Journal of Agricultural Research, 17 (4), e0806.

Aras, S., Keles, H., \& Bozkurt, E. (2021). Physiological and histological responses of peach plants grafted onto different rootstocks under calcium deficiency conditions. Scientia Horticulturae, 281, 109967.

Bolat, I., Dikilitas, M., Ikinci, A., Ercisli, S., \& Tonkaz, T. (2016). Morphological, physiological, biochemical characteristics and bud success responses of myrobolan 29 c plum rootstock subjected to water stress. Canadian Journal of Plant Science, 96(3), 485493.

Boyer, J. S. (1988). Cell enlargement and growth-induced water potentials. Physiologia Plantarum, 73(2), 311316.

Chatelet, D. S., Rost, T. L., Shackel, K. A., \& Matthews, M. A. (2008). The peripheral xylem of grapevine (Vitis vinifera). 1. Structural integrity in post-veraison berries. Journal of Experimental Botany, 59(8), 19871996.

Cochard, H., Barigah, S. T., Kleinhentz, M., \& Eshel, A. (2008). Is xylem cavitation resistance a relevant criterion for screening drought resistance among Prunus species?. Journal of Plant Physiology, 165(9), 976-982. 
Cochard, H., Damour, G., Bodet, C., Tharwat, I., Poirier, M., \& Améglio, T. (2005). Evaluation of a new centrifuge technique for rapid generation of xylem vulnerability curves. Physiologia Plantarum, 124(4), 410-418.

Dražeta, L., Lang, A., Hall, A. J., Volz, R. K., \& Jameson, P. E. (2004). Causes and effects of changes in xylem functionality in apple fruit. Annals of Botany, 93(3), 275-282.

Çıkman, E., Çömlekçioğlu, N., \& Şimşek, M. (2011). Effects of different irrigation levels on population densities of liriomyza trifolii (burgess, 1880) on two vegetable soybean (Glycine max [l.] merr.) cultivars. Harran Tarım ve Gıda Bilimleri Dergisi, 15(3), 29-35.

Grimm, E., Pflugfelder, D., van Dusschoten, D., Winkler, A., \& Knoche, M. (2017). Physical rupture of the xylem in developing sweet cherry fruit causes progressive decline in xylem sap inflow rate. Planta, 246(4), 659672.

Hargrave, K. R., Kolb, K. J., Ewers, F. W., \& Davis, S. D. (1994). Conduit diameter and drought-induced embolism in Salvia mellifera Greene (Labiatae). New Phytologist, 126(4), 695-705.

Inch, S. A., \& Ploetz, R. C. (2012). Impact of laurel wilt, caused by Raffaelea lauricola, on xylem function in avocado, Persea americana. Forest Pathology, 42(3), 239-245.

Li, H., Zhang, X., Hou, X., \& Du, T. (2021). Developmental and water deficit-induced changes in hydraulic properties and xylem anatomy of tomato fruit and pedicel. Journal of Experimental Botany, 72(7), 27412756.

Liu, Y. Y., Song, J., Wang, M., Li, N., Niu, C. Y., \& Hao, G. Y. (2015). Coordination of xylem hydraulics and stomatal regulation in keeping the integrity of xylem water transport in shoots of two compound-leaved tree species. Tree Physiology, 35(12), 1333-1342.

Martinez, H. E. P., Maia, J. T. L. S., Ventrela, M. C., Milagres, C. D. C., Cecon, P. R., Clemente, J. M., \& Garbin, C. Z.
(2020). Leaf and stem anatomy of cherry tomato under calcium and magnesium deficiencies. Brazilian Archives of Biology and Technology, 63, e20180670.

Meinzer, F. C., Clearwater, M. J., \& Goldstein, G. (2001). Water transport in trees: current perspectives, new insights and some controversies. Environmental and Experimental Botany, 45(3), 239-262.

Miqueloto, A., do Amarante, C. V. T., Steffens, C. A., dos Santos, A., \& Mitcham, E. (2014). Relationship between xylem functionality, calcium content and the incidence of bitter pit in apple fruit. Scientia Horticulturae, 165, 319-323.

Polat, A. A. (2021). Investigation on the usage of hawthorn (Crataegus spp) as rootstock for loquat (Eriobotrya japonica Lindl.). Harran Tarım ve Gıda Bilimleri Dergisi, 25(1), 86-91.

Rajput, V. D., Chen, Y., \& Ayup, M. (2015). Effects of high salinity on physiological and anatomical indices in the early stages of Populus euphratica growth. Russian Journal of Plant Physiology, 62(2), 229-236.

Sano, Y., Okamura, Y., \& Utsumi, Y. (2005). Visualizing water-conduction pathways of living trees: selection of dyes and tissue preparation methods. Tree Physiology, 25(3), 269-275.

Stiller, V. (2009). Soil salinity and drought alter wood density and vulnerability to xylem cavitation of baldcypress (Taxodium distichum (L.) Rich.) seedlings. Environmental and Experimental Botany, 67(1), 164-171.

Tezara, W. M. V. J., Mitchell, V. J., Driscoll, S. D., \& Lawlor, D. W. (1999). Water stress inhibits plant photosynthesis by decreasing coupling factor and ATP. Nature, 401(6756), 914-917.

Umebayashi, T., Utsumi, Y., Koga, S., Inoue, S., Shiiba, Y., Arakawa, K., Matsumura, J., \& Oda, K. (2007). Optimal conditions for visualizing water-conducting pathways in a living tree by the dye injection method. Tree Physiology, 27(7), 993-999. 